поштограми, телеграми, листи до ЦК, де звітувалося про кількість вмерлих, а хто ще дихав - того віддавали до суду.

Якщо історія подає лише сухі цифри та дати, за якими стоять певні події, то книга Миколи Томенка емоційно та образно торкається душі кожного, хто прочитає іiі, і навіть сьогоднішне покоління, для якого за словом «трудодень» нічого не стоїть, починає розуміти ту епоху краще, адже книга внесена до вивчення у шкільну програму.

\title{
Література:
}

1. Білоус Дмитро. Важка дорога до правди // Повертаюсь сьогодні до себе. Микола Томенко в колі друзів. К. Видавництво «Щек», 2017. C. 120 .

2. Жулинський Микола. Білі автографи української долі // Повертаюсь сьогодні до себе. Микола Томенко в колі друзів. К. Видавництво «Щек», 2017. С.131.

3. Томенко Микола. Трудова книжка матері. К. Видавництво «Фенікс», 2008. 307 с.

DOI https://doi.org/10.30525/978-9934-26-180-0-12

\section{АВТОКРЕАЦИЯ ТВОРЧЕСКОЙ ЛИЧНОСТИ В РАССКАЗАХ СБОРНИКА А. Н. ГАВРИЛОВА «ВОПЛЬ ВПЕРЕДСМОТРЯЩЕГО»}

\author{
Шеховцова Т. А. \\ доктор филологических наук, \\ профессор кафедры истории русской литературы \\ Харьковский национальный университет имени В. Н. Каразина \\ г. Харьков, Украина
}

Сборник А. Н. Гаврилова «Вопль впередсмотрящего» (2011) включает одноименную повесть, 15 рассказов и пьесу «Играем Гоголя». Рассказы, вошедшие в книгу, обладают внутренним единством и могут рассматриваться как авторский сборник-цикл или даже единый текст. Целостность этого «сборника в сборнике» обеспечивают сквозные темы и мотивы, повторяющиеся ситуации, внутренний сюжет, композиция, образ героя-повествователя. 
Последовательность рассказов задана автором: «Последняя надежда», «Снег прикроет», «Нужно бороться», «Нужно держаться», «Нужно подумать», «Иди и пиши», «Пора кончать», «Мы еще встретимся?», «А снег идет», «Где солнце?», «Осенняя прогулка», «7 ноября», «День писателя», «Вчера и сегодня внутри нас», «Знать меру». Названия рассказов создают определенную смысловую цепочку, в которой просматриваются внутренние закономерности, не столько логические, сколько эмоционально-лирические. Лирический сюжет связан с динамикой переживаний, чувств, мыслей героя-повествователя, во многом автобиографического. Надежда и отчаяние, тупик и свет в конце тоннеля, поиски духовных опор, самовоспитание и попытки самооправдания - главные составляющие этого сюжета.

Большинство рассказов имеют открытые финалы, поэтому каждый следующий продолжает предыдущий. Первостепенной темой сборника является тема литературного творчества. Лирический герой (повествователь) - пишущий человек. Упоминания о литературе, писателях, творчестве присутствуют почти в каждом произведении. В рассказах сталкиваются два плана - возвышенный и низменный. Высокий план - литература и искусство, великие писатели и художники, творчество, любовь, мечта, красота. Низкий план - проза жизни, грязной и неухоженной, убивающей мечты и надежды. В этом мире живут рабочие, почтальоны, распространители БАДов, водители, инвалиды. Они работают и отдыхают, копают картошку и возят цемент, пьют водку и чай, ездят автобусами. Лирический герой Гаврилова, на первый взгляд, ничем не отличается от других персонажей. Единственное отличие - это умение из очень немногих слов и самых прозаических впечатлений составлять рассказы. И это умение накладывает на маленького человека особую ответственность - за себя и за свое творчество. Но герой не может избавиться от бытовой прозы и человеческой слабости в себе: он берет в библиотеке «Жизнь Гогена» и покупает бутылку водки с плавленым сырком («Осенняя прогулка»).

В открывающем сборник рассказе «Последняя надежда» высокий план задан именем писателя Борхеса и воспоминанием героя о первом танго с прекрасной девушкой. Низкий план - металлургический завод имени Ильича, цемент на даче, игра в домино, сниженная обиходная лексика. Два плана неожиданно смыкаются иронической концовкой: герой перебирает книги, отыскивая в них спрятанные 100 рублей, и томик Борхеса становится последней надеждой, которая не сбылась. Столкновение высокого и низкого, снижение высокого - любимый прием Гаврилова. В рассказе «Осенняя прогулка» просьба дать на короткое время 
Леви-Стросса свидетельствует не только об общем круге чтения собеседников-интеллектуалов. Именем французского структуралиста Леви-Стросса с иронией называют сантехнический трос для прочистки канализации.

В рассказе «Снег прикроет» ассоциации выводят на обобщение: нелетающие самолеты - бескрылый человек, который не может и не хочет улучшить себя и мир вокруг. На субботник не выходит никто, кроме инвалида. Вывод: «снег прикроет, успокойся» произносит чей-то голос, может быть, внутренний голос повествователя, утешающего самого себя в своем бездействии.

Герой пытается принудить себя к активным действиям: организовать ремонт дома, пойти на встречу с читателями, написать рассказ: «Пойду сегодня. Идти не хочется, но нужно. <..> Нужно преодолеть себя и идти. Нужно бороться» $[1$, с. 218$]$. Но борьба с собой - самая трудная форма борьбы.

В рассказе под названием «Нужно подумать» 14 раз повторяются эти слова. Повествователь произносит их по любому поводу, от бытового до экзистенциального, причем не дает конкретного ответа на вопросы и ничего не предпринимает. Это объединяет его с другими персонажами Гаврилова, которые не способны принять решение, сделать шаг вперед. Однако в финале шаг все же сделан: герой приходит в библиотеку на встречу с читателями и обходит стороной закусочную - еще один сквозной образ, олицетворяющий повседневные соблазны.

В рассказе «Иди и пиши» также присутствуют два плана. Первый план - цветущий май, огромное чистое солнце, герой, бегущий к чему-то необыкновенному, чудесная девушка. Второй план - поход за цементом, пьяный отец, чье-то правонарушение, за которое задерживают героя. Встреча с капитаном милиции, который верит юноше и велит ему: «Иди и пиши», оказывается судьбоносной. Письменные показания свидетеля превращаются в творчество. Последняя фраза это подтверждает: «Вспомнилось давно прошедшее, я выключил телевизор, выпил за здоровье капитана и сел писать» [1, с. 230].

В рассказе «Пора кончать» главным героем становится диван. Трудно не вспомнить диван Обломова, потому что этот герой тоже с большим трудом решался начать любое дело. У Гаврилова диван не тянет к отдыху, а напротив, является призывом к действию: он нуждается в ремонте. Этот диван упоминается и в рассказе «День писателя», где мы снова видим художника, уклоняющегося от творчества. Однако это творчество под надзором. У героя появляется свой Штольц - приятель, который пытается 
его стимулировать: «А ты - работай. Не спи, не спи, художник!» [1, с. 259]. После ухода приятеля писатель ложится на диван.

Последний рассказ сборника имеет неожиданное название «Знать меру». Повествователь вспоминает о знакомстве с девушками-студентками, о своих намерениях учиться, интеллектуально совершенствоваться. Но намерения не сбываются: «В тот день я никуда не пошел, так как проспал» [1, с. 267]. Герой снова идет в закусочную, хоть и признается, что лучше бы туда не заходить. В финале вновь возникает диалог с внутренним голосом, который можно интерпретировать и как голос свыше, от какого-нибудь высшего существа, Бога или Музы: «Но разве возможно? «Возможно», - услышал я чей-то голос и замолчал» [1, с. 268]. Финал остается открытым. Жизнь продолжается, как продолжается и творчество, и борьба с собой.

История жизни как духовных блужданий, падений и взлетов героя передана в лирическом сюжете, проходящем через весь сборник. Вся жизнь героя, от рассказа к рассказу, - это борьба со своими слабостями, с апатией, сомнениями, нежеланием что-либо делать, заставлять себя. Повествователь не теряет надежду преодолеть в себе экзистенциальную тоску, ведущую к бездействию и беспомощности. Эту мысль подтверждают слова из рассказа: «Где солнце?»: «Солнца по-прежнему нет. Может, ему уже не хочется освещать и обогревать нашу грешную землю? Солнце, мы исправимся, выходи» [1, с. 245].

Единство видения и единство изображаемого мира подчеркиваются сквозными мотивами: опавших листьев, дождя, солнца, ветра, снега, птиц, полета (самолета), голоса, танца, книги (библиотеки), музыки, песни, мечты, творчества, праздника, пития, сна. Они определяют важные константы человеческого бытия. Мотивы могут образовывать контрастные, оппозиционные пары: черный/белый, свет/тьма, тепло/холод. Почти все эти мотивы получают символическое значение, связанное с духовным состоянием героя. Устойчивым мотивом становится также мотив несостоявшегося действия, несбывшейся мечты.

Еще одна оппозиция, которую можно выделить в структуре рассказов и сборника в целом, - это противопоставление «несостоявшийся праздник»/《праздник, который всегда с тобой». «Поиски праздников» часто завершаются «плохим поведением» («Необходимо держаться»). Спасением от безнадежно й жизни может стать творчество. Однако лирическому герою присущи сомнения в своих способностях, муки творчества, страх шаблона, штампа, что иногда тоже приводит к отказу от творческой деятельности: «и все это многократно описывалось беллетристами, так многократно, что уже тошно и читать, и говорить об 
этом» [1, с. 232]. Учитывая эти размышления, название рассказа «Пора кончать» и его финал (убийство героя во сне) можно интерпретировать и как убийство в себе писателя-неудачника.

Фрагменты произведений повествователя трудно отличить от его рассказа о своей или чужой жизни. Они никак не маркированы и представляют собой своеобразный «текст в тексте», стилистически и поэтически однородный с окружающими фрагментами. При этом в рассказы вводится автометатекстуальный компонент, то есть размышления автора над своим текстом в процессе его создания. Жизнь переходит в литературу и наоборот.

Основными циклообразующими факторами сборника можно считать лирический сюжет, воспроизводящий историю не столько физического, сколько духовного бытия героя; сквозные символические мотивы, придающие повествованию универсальный смысл; образ автораповествователя, который существует в том же мире, что и другие персонажи, но сочетает в себе черты маленького человека и способности художника, человеческие слабости и тягу к творчеству. В лирическом герое Гаврилова совмещаются автобиографическое начало (прежде всего, писательские характеристики) и типичные приметы обитателя провинциальной глубинки, погруженного в прозу повседневности и в то же время стремящегося к лучшей жизни. Размывая границы между жизнью и литературой, самоописание лирического героя предстает в полном смысле слова самотворением, или автокреацией, то есть формой самосовершенствования и самореализации личности через творческую деятельность.

\section{Литература:}

1. Гаврилов А. Вопль впередсмотрящего. М. : Колибри, Азбука-Аттикус, 2011. 304 с. 